\title{
Comparative Study of Residential Household Energy Consumption in Ekiti State-Nigeria
}

\author{
O. T. Oginni ${ }^{1 *}$, O. L. Rominiyi ${ }^{2}$ and J. F. Eiche ${ }^{1}$ \\ ${ }^{1}$ Department of Mechanical Engineering, Federal University of Technology Akure (FUTA), \\ Ondo State, Nigeria. \\ ${ }^{2}$ Department of Mechanical and Mechatronics Engineering, Afe Babalola University Ado-Ekiti \\ $(A B \cup A D)$, Ekiti State, Nigeria.
}

\begin{abstract}
Authors' contributions
This work was carried out in collaboration between all authors. All authors read and approved the final manuscript.

Article Information

DOI: 10.9734/BJAST/2017/32374

Editor(s):

(1) Rodolfo Dufo Lopez, Electrical Engineering Department, University of Zaragoza, Spain.

Reviewers:

(1) S. B. Shamaki, Usmanu Danfodiyo University, Sokoto, Nigeria. (2) Sreekanth, Kuwait Institute for Scientific Research, Kuwait. (3) Jakub Jurasz, AGH University, Poland. Complete Peer review History: http://www.sciencedomain.org/review-history/19329
\end{abstract}

Original Research Article

Received $23^{\text {rd }}$ February 2017 Accepted $17^{\text {th }}$ April 2017 Published $3^{\text {rd }}$ June 2017

\begin{abstract}
Aims: The paper compares the residential household energy consumption pattern between the densely and sparsely populated dwellers on the basis of income level classification with a view to ensuring functional distribution of energy. This study identified, determined and evaluated the various households' energy choices, quantities and costs of domestic energy consumption and provided a database for documentation.

Place and Duration of Study: Department of Mechanical Engineering, Federal University of Technology, Akure, Ondo State, Nigeria, between December 2014 and March 2015.

Methodology: Primary data were collected through a well structured questionnaires administered on households. Direct and personal observations were used to corroborate same information obtained from the questionnaires used to present more accurate information in the paper. Data obtained were analyzed using both independent and paired t-tests conducted at 5 and $10 \%$ levels of significance in the annual energy consumption between the low and high income earners in the visited areas respectively.
\end{abstract}


Results: The result revealed that, the densely populated area remains the larger consumer of energy content of $827,411.20 \mathrm{MJ}(63 \%)$ against the sparsely populated areas with $486,267.60 \mathrm{MJ}$ $(37 \%)$, while on the basis of households' income level; the energy consumed by the low income earners $(790,719.30 \mathrm{MJ})$ is significantly higher than the high income earners (522,959.49 $\mathrm{MJ})$.

Conclusion: The study established that, fuel wood was the poor man's energy source $(6.5 \%)$ as well as charcoal $(11.2 \%)$ majorly used in sparsely populated areas with high demand. Kerosene consumption (29.6\%) was positively and significantly influenced by income and population in both locations while, LPG $(44.9 \%)$ and electricity $(7.8 \%)$ were used mainly in the densely populated areas. However, the results implied that, there was a positive link between income and choice of energy consumption by households that showed the low income earners consumed more energy than the high income earners due to their cooking frequency and unit energy purchase index.

Keywords: Energy choices; residential household; sparsely and densely populated areas; Ekiti State.

\section{INTRODUCTION}

Energy plays the most vital role in the economic growth, progress, and development, as well as poverty eradication and security of any nation. Hence, the geometrical growing annually at an alarming rate of energy consumption all over the world and need to adopt the energy policy that encourages the efficient usage of limited electricity supply is required. It is on this note that, the standard of living of a given country can be directly related to the per capital energy consumption [1]. The world consumes about 7500 Mtoe of energy every year, while primary energy consumption will grow by almost $50 \%$ from $2005-2030$. About $30-40 \%$ of all the primary energy is used in residential building worldwide [2] which is equivalent to 2500 Mtoe every year. It is an established fact that, the building sector is responsible for a large share of the world's total energy consumption. The pattern of energy usage in Nigeria's economy can be divided into industrial, transport, commercial, Agricultural and household sectors [3]. The household sector accounts for the largest share (about 65\%) of energy usage in the country. The major energyconsuming activities in Nigeria's household are cooking, lighting and use of electrical appliances. Cooking accounts for a staggering $91 \%$ of household energy consumption, lighting uses up to $6 \%$ and the remaining $3 \%$ can be attributed to the use of basic electrical appliances such as televisions and pressing irons [2]. Energy consumed by households in developing countries such as Nigeria includes electricity, gas, diesel, kerosene, inverters, candles, lanterns, fuel wood, charcoal, sawdust etc. The energy consumption pattern largely depends on the types of dwelling, occupant numbers, household incomes and climate zones. In most Nigerian homes, it is evident that energy efficiency is not factored in the choice of household appliances and electrical fittings. It could therefore be argued that, electrical energy utilization in Nigeria is far from being efficient as in most homes; filament bulbs of wattages ranging 40 watts to 120 watts per hour reported [4]. Households in different parts of the world have different levels of energy consumption based on climate and income [5]. The domestic energy consumption is the amount of energy that is spent on the various appliances used within the house and the amount of energy used per household depending on the standard of living of the country, climate, age and the type of residence. Hence, energy consumption at the household level is a key indicator of standard of living [6]. The domestic energy consumption accounts for about $80 \%$ of the total energy consumption in developing countries [7]. In his study of household energy preference for cooking in urban Burkina faso [8], he realized that household cooking energy preference is due to poverty factors while World Bank study in 2004 shows that, there is a high relation between the level of poverty and the energy use for cooking by household. The massive increased in the cost of modern fuel has increased the level of poverty of Nigerians left wood as the fuel of choice for most households in rural areas [9].

World energy consumption refers to the total energy used by all of human civilization. Typically measured per-year, it involves all energy harnessed from energy source as applied towards humanity's endeavours across every industrial and technological sectors across every explorers. The amount of energy used per household varies widely depending on the economic status of people of the country and type of homes among others. Energy resources can be classified on the basis of their renewability as (i) Renewable and (ii) Nonrenewable [10]. Renewable energy sources are 
sources that can be replenished or produced quickly through natural processes. The rate at which they are used does not affect their availability in future and as such cannot be exhausted. All the regions of the world have reasonable access to one or more forms of renewable energy supply because the resources are generally well distributed all over the world at wide spatial and temporal variation [11]. Despite the fact that, Nigeria is a rich country blessed with a lot of energy resources such as, wind, biomass, crude oil, national gas and coal, yet an estimated number of $60-70 \%$ of Nigerians population does not have access to electricity.

At present, Nigeria energy supply is almost entirely dependent on fossil fuels and firewood which are depleting fast [10]. The 1995 distribution of energy consumption typified the current energy supply mix in the country which shows that the total energy consumption, the share of natural gas was $5-22 \%$, hydroelectricity took $3.05 \%$, fuel wood had a lion share of $50.45 \%$ and petroleum product had $41.23 \%$ share. This depicts the splitting essentiality between hydroelectricity and traditional fuel wood [12]. The most important energy sector of the Nigerian economy is the household sector presently dominating the highest energy consumption in Nigeria [11]. Hence, the necessity of renewable energy in meeting the future energy need in both rural and urban area [13]. Nigeria receives abundant solar energy that can be usefully harnessed with an annual average daily solar radiation of $5.25 \mathrm{kWh} / \mathrm{m}^{2} /$ day, falls on the entire land area of Nigeria that is 120,000 times the total annual average electrical energy generated by the Power Holding Company of Nigeria [14]. With a $10 \%$ conservative conversion efficiency, the available solar energy resources is about 23 times the energy commission of Nigeria's projection of the total final energy demand for Nigeria in the year 2030 [2]. Research indicated that the identified feedstock substrate for an economically feeble biogas programmed in Nigeria include Water Lettuce, Water Hyacinth, Dung, Cassava Leaves, Urban Refuse, Solid Waste, Agricultural Residues and Sewage, produces about 227500 tonnes of fresh animal wastes daily [12]. Since 7 $\mathrm{kg}$ of fresh animal waste produce a about 0.03 $\mathrm{m}^{3}$ gases, then; Nigeria could produce about 6.8 million $\mathrm{m}^{3}$ of biogas every day. Economic factor plays an important role in the choice of energy used for cooking. However, this research work has critically examined, quantified and evaluated by analysis the relation between energy consumption and monthly income levels of the Nigerians.

\section{DATA COLLECTION AND ANALYSIS TOOLS}

The data were collected through a well structured questionnaires administered on households. Direct and personal observations were used to corroborate same information obtained from the questionnaires used to present more accurate information. Data obtained was analysed with the aid of descriptive statistical tool, Independent and Paired t- tests.

\subsection{The Study Area}

Ekiti state is one of the states in south-western Nigeria, created on October 1, 1996. It has landlocked area of between 5,800 and 6,400 square kilometres with 16 local governments and a census population of about 1.6 million $(1,647,822$ by 2006 census) [15]. Ten local government areas were selected within Ekiti state relative to their population densities, income, available infrastructural facilities and economic growth in the visited locations. The study determined the relation between the residential household energy consumption in Sparsely Populated Area (SPA) and Densely Populated Area (DPA) among Ikole, Ekiti West, Ekiti South West, Ado, ljero, Emure, Ise-Orun, Irepodun/Ifelodun, Efon and llejemeje local government areas.

\subsection{Sample and Sampling Techniques}

Ten local government areas of Ekiti state were considered through their population densities and available facilities via densely and sparsely populated areas as the major determinant of location comparison. The study covered the following local government areas and the randomly selected towns as shown in Table 1 by 2006 population census.

\subsection{Research Instrument}

The questionnaire used in the study consists mainly of questions whose answers are optional, designed to address social-economic characteristics (age, family size and frequency of cooking, safety and convenience, educational qualification, occupation, monthly income, type of dwelling place), types of cooking energy by households according to location (fuel wood, charcoal, kerosene, cooking gas, electricity), quantity of energy consumed, number of hours 
Table 1. List of selected local governments and areas visited in Ekiti State with 2006 population census [16]

\begin{tabular}{|c|c|c|c|c|c|}
\hline LG & $\begin{array}{l}2006 \\
\text { census }\end{array}$ & $\begin{array}{l}\text { Areas } \\
\text { visited }\end{array}$ & $\begin{array}{l}2006 \\
\text { populations }\end{array}$ & $\begin{array}{l}\text { Population } \\
\text { density }\end{array}$ & $\begin{array}{l}\text { Facilities/ infrastructures /types of } \\
\text { dwelling places }\end{array}$ \\
\hline Ado & 313,690 & Ado & 256,265 & $\begin{array}{l}\text { Densely } \\
\text { Populated }\end{array}$ & $\begin{array}{l}\text { Universities, Polytechnics, Technical } \\
\text { college, Schools, Factories, Filling } \\
\text { Stations, Duplex, Detached, Flats, } \\
\text { Hospitals, and Teaching Hospital. }\end{array}$ \\
\hline ljero & 221,873 & $\begin{array}{l}\text { Ijero } \\
\text { Ikoro }\end{array}$ & $\begin{array}{l}45,268 \\
31,098\end{array}$ & $\begin{array}{l}\text { Densely } \\
\text { Populated }\end{array}$ & $\begin{array}{l}\text { College of Health Sciences, Teaching } \\
\text { Hospital, Schools, Wood Processing } \\
\text { Factories, Duplex, Flats, Filling } \\
\text { Stations, and Clinics. }\end{array}$ \\
\hline Ekiti West & 179,244 & $\begin{array}{l}\text { Aramoko } \\
\text { Okemesi }\end{array}$ & $\begin{array}{l}42,191 \\
35,792\end{array}$ & $\begin{array}{l}\text { Densely } \\
\text { Populated }\end{array}$ & $\begin{array}{l}\text { Schools, Wood Processing Factories, } \\
\text { Duplex, Flats, Filling Stations, and } \\
\text { Hospitals. }\end{array}$ \\
\hline Ikole & 170,414 & $\begin{array}{l}\text { Ikole } \\
\text { OdoAyedu } \\
\text { n }\end{array}$ & $\begin{array}{l}25,601 \\
16,133\end{array}$ & $\begin{array}{l}\text { Densely } \\
\text { Populated }\end{array}$ & $\begin{array}{l}\text { University, Technical College, } \\
\text { Schools, Wood Processing Factories, } \\
\text { Duplex, Flats, Filling Stations, and } \\
\text { Hospitals. }\end{array}$ \\
\hline $\begin{array}{l}\text { Ekiti South } \\
\text { West }\end{array}$ & 165,087 & $\begin{array}{l}\text { llawe } \\
\text { IgbaraOdo }\end{array}$ & $\begin{array}{l}78,961 \\
42,528\end{array}$ & $\begin{array}{l}\text { Densely } \\
\text { Populated }\end{array}$ & $\begin{array}{l}\text { University Study Centre, Technical } \\
\text { College, Wood Processing Factories, } \\
\text { Flats, Filling Stations and Hospitals. }\end{array}$ \\
\hline Irepodun & 131,330 & $\begin{array}{l}\text { Awo } \\
\text { Afao }\end{array}$ & $\begin{array}{l}11,069 \\
5,631\end{array}$ & $\begin{array}{l}\text { Sparsely } \\
\text { Populated }\end{array}$ & $\begin{array}{l}\text { Schools, Filling Stations, Flats, and } \\
\text { Health Centres. }\end{array}$ \\
\hline Ise-orun & 113,951 & $\begin{array}{l}\text { OrunEkiti } \\
\text { OgbeseEki } \\
\text { ti }\end{array}$ & $\begin{array}{l}6,595 \\
4,057\end{array}$ & $\begin{array}{l}\text { Sparsely } \\
\text { Populated }\end{array}$ & $\begin{array}{l}\text { Schools, Filling Station, Flats, Health } \\
\text { Centres ; and Room and Parlour. }\end{array}$ \\
\hline Emure & 94,264 & $\begin{array}{l}\text { Eporo } \\
\text { Oge }\end{array}$ & $\begin{array}{l}10,212 \\
1,355\end{array}$ & $\begin{array}{l}\text { Sparsely } \\
\text { Populated }\end{array}$ & $\begin{array}{l}\text { Schools, Health Centre; and Room } \\
\text { and Parlour.. }\end{array}$ \\
\hline Efon & 87,187 & $\begin{array}{l}\text { Omoniafe } \\
\text { Camp } \\
\text { Araromi } \\
\text { Camp }\end{array}$ & $\begin{array}{l}1,008 \\
857\end{array}$ & $\begin{array}{l}\text { Sparsely } \\
\text { Populated }\end{array}$ & $\begin{array}{l}\text { Primary School, Single Rooms and } \\
\text { Huts. }\end{array}$ \\
\hline Ilejemeje & 43,459 & $\begin{array}{l}\text { ljesamodu } \\
\text { EdaOniyo }\end{array}$ & $\begin{array}{l}4,509 \\
3,904\end{array}$ & $\begin{array}{l}\text { Sparsely } \\
\text { Populated }\end{array}$ & $\begin{array}{l}\text { Schools, Filling Station, Room and } \\
\text { Parlours, and Health Centre. }\end{array}$ \\
\hline
\end{tabular}

used per day, cooking energy satisfied or unsatisfied, and factors influencing choice of energy use and the utmost index of measuring energy consumption via cost implications. Fifty (50) copies of questionnaire were administered to the respondents in each local government areas selected.

\subsection{Estimation of Energy Consumption}

In order to estimate energy consumption of an appliance, there is need to know its wattage and the number of hours that such appliance is in use per day. The wattage can be found on the number of nameplate or manufacturer's websites and calculated in kilowatt hour for a unit, the energy consumption $(w w w, 2014)$ is estimated thus;

$$
\mathrm{D}=\mathrm{pt}
$$

Annual consumption is calculated by multiplying the result from this formula by the number of days that the appliance is in use throughout the year.

$$
A=p f r
$$

In order to estimate annual cost of running an appliance, multiply the annual kilowatt-hour consumption in kWh by local utility rate of cost per kWh [17].

$$
\mathrm{C}=\mathrm{re}
$$

Where; $A$ is the annual consumption, $D$ is the daily consumption, $p$ is the wattage of each appliance, $t$ is the hours used per day, $f$ is the number of days used per year, $C$ is the cost of annual consumption, $e$ is the annual energy consumption and $r$ is the local utility rate. 
Table 2. Determination of energy consumption and cost evaluation in Ekiti State [18]

\begin{tabular}{lllllllc}
\hline Energy & $\begin{array}{l}\text { Mass of } \\
\text { energy } \\
(\mathbf{k g})\end{array}$ & $\begin{array}{l}\text { Heating } \\
\text { value } \\
(\mathbf{M J} / \mathbf{k g})\end{array}$ & $\begin{array}{l}\text { Energy } \\
\text { factor } \\
(\mathbf{M J} / \mathbf{h r})\end{array}$ & $\begin{array}{c}\frac{\text { Price }}{\text { Unit }} \\
(\mathrm{N} / \mathbf{k g})\end{array}$ & $\begin{array}{c}\text { Cost } \\
(\mathrm{A})\end{array}$ & $\begin{array}{c}\text { Energy } \\
(\mathbf{M J})\end{array}$ & $\begin{array}{c}\frac{\text { Cost }}{\text { Energy }} \\
(\mathrm{N} / \mathbf{M J})\end{array}$ \\
\hline Charcoal & $\mathrm{A}$ & 28.0 & 7.8 & $\mathrm{~A}$ & $A a$ & $28 \mathrm{~A}$ & $\frac{a}{28.0}$ \\
Cooking Gas & $\mathrm{B}$ & 46.6 & 6.6 & $\mathrm{~B}$ & $B b$ & $46.6 \mathrm{~B}$ & $\frac{b}{46.6}$ \\
Electricity & $\mathrm{C}$ & 3.6 & 3.6 & $\mathrm{C}$ & $\mathrm{Cc}$ & $3.6 \mathrm{C}$ & $\frac{c}{3.6}$ \\
Fuel wood & $\mathrm{D}$ & 16.0 & 4.4 & $\mathrm{D}$ & $\mathrm{Dd}$ & $16 \mathrm{D}$ & $\frac{d}{16.0}$ \\
Kerosene & $\mathrm{E}$ & 43.0 & 9.8 & $\mathrm{E}$ & $E e$ & $43 \mathrm{E}$ & $\frac{e}{43.0}$ \\
\hline
\end{tabular}

In this paper, five different domestic households' energy choices were considered in this paper namely: fuel wood, charcoal, electricity, kerosene and liquefied petroleum gas. The parameters used for estimating various household's energy choices are shown in above Table 2.

\subsection{Method of Data Analysis}

The data generated were organized and analyzed using simple arithmetic and percentages to access the respondents' view on the research questions. The following statistical tools were used.

(a) Descriptive statistical analysis was used to analyze socio-economic characteristics of respondents on monthly income level and type of cooking energy, weather influence and locations.

(b) Independent t- test comparison was used for testing the validity of data collected.

(c) Paired t- test comparison was employed for confirmatory test of the data obtained.

\section{RESULTS AND DISCUSSION}

Table 3 showed the total energy consumed by various households' energy choices in the ten selected local government in Ekiti State.

Table 4 and Table 5 showed the quantity of energy consumed by the households in both DPA and SPA in the studied areas with their evaluated energy choices' cost respectively. The energy consumed (827,411.20 MJ) and cost $(\$ 3,831,886.29)$ in DPA is higher than SPA with a total energy of $486,267.60 \mathrm{MJ}$ and cost of \#1,527,236.66.

\subsection{Results Analysis between Low and High Income Earners}

Tables 4 and 5 showed by analysis the results obtained from households' energy consumption in the ten selected locations.

\subsection{Results Analysis between Low and High Income Earners Using Independent t- test}

Table 8 showed the analysis by application the use of independent t-test to establish the relationship between the energy consumed by the low and high income earners. It was evident from the evaluation that, the low income earners consumed more energy than the high income earners.

From t- table, $\left(t_{18}, 1-\frac{0.05}{2}\right)$ and at $5 \%$ level of significant; the low income earners had 47,016.16 MJ and the high income earners consumed 6,535.80MJ. Likewise, from ttable, $\left(t_{18}, 1-\frac{0.05}{2}\right)$ and at $10 \%$ level of significant, $43,450.03 \mathrm{MJ}$ was consumed by the low income earners while the high income earners consumed 10,101.93 MJ. It is obvious from the above evaluation data in Table 4 that, at $5 \%$ level of significant, the true difference between the energy consumption by low income earners and that of high income earners are $47,016.16 \mathrm{MJ}$ to $6,535.80 \mathrm{MJ}$. But at $10 \%$ level of significance the true difference between the energy consumption by households in Ekiti state in both income groups were 43,450.23 MJ in favour of low income earners and 10,101.93 MJ in favour of high income group. 
Table 3. Energy consumption by household cooking energy choices in Ekiti State

\begin{tabular}{|c|c|c|c|c|c|c|c|c|c|c|c|c|}
\hline & Ado & ljero & E W & Ikole & ES W & Irepodun & Ise-Orun & Emure & Efon & Ilejemeje & Total & $\%$ \\
\hline C & $12,030.4$ & $11,052.2$ & $10,220.0$ & $10,512.0$ & $15,768.0$ & $17,045.5$ & $22,206.6$ & $17,082.0$ & $15,373.8$ & $16,556.4$ & $147,846.9$ & 11.3 \\
\hline $\mathrm{L}$ & $129,042.1$ & $104,233.1$ & $103,076.0$ & $77,307.0$ & $69,576.3$ & $23,352.7$ & $20,082.3$ & $20,016.6$ & $26,688.8$ & $16,680.5$ & $590,055.4$ & 44.9 \\
\hline$E$ & $20,899.9$ & $13,687.5$ & $15,768.0$ & $10,512.0$ & $9,800.3$ & $13,344.4$ & $5,124.6$ & $3,416.4$ & $5,124.6$ & $4,752.3$ & $102,429.9$ & 7.8 \\
\hline $\mathrm{F}$ & $3,073.3$ & $5,562.6$ & $5,263.3$ & $5,358.2$ & $3,949.3$ & $13,753.2$ & $10,249.2$ & $13,665.6$ & $11,957.4$ & $11,957.4$ & $84,789.5$ & 6.5 \\
\hline $\mathrm{K}$ & $36,500.0$ & $40,427.4$ & $38,456.4$ & $41,661.1$ & $33,674.9$ & $59,319.8$ & $35,430.6$ & $38,478.3$ & $31,262.3$ & $33,346.4$ & $388,557.1$ & 29.6 \\
\hline $\mathrm{T}$ & $201,545.7$ & $174,962.8$ & $172,783.7$ & $145,350.3$ & $132,768.8$ & $126,815.6$ & $93,093.3$ & $92,658.9$ & $90,406.7$ & $83,293.0$ & $1,313,678.8$ & 100 \\
\hline
\end{tabular}

Table 4. Energy consumption and cost evaluation of Domestic Household Cooking Energy choices (DHCE) in densely populated areas

\begin{tabular}{llll}
\hline S/N & LG & Energy consumption of DHCE in densely populated areas (MJ) & Cost (N) \\
\hline 1 & Ado & $201,545.70$ & $971,981.62$ \\
2 & ljero & $174,962.75$ & $814,889.06$ \\
3 & Ekiti west & $172,783.70$ & $809,563.21$ \\
4 & IkoleWest & $145,350.30$ & $651,965.20$ \\
5 & Ekiti South & $132,768.75$ & $583,487.20$ \\
& Total & $827,411.20(63 \%)$ & $3,831,886.29$ \\
\hline
\end{tabular}

Table 5. Energy consumption and cost evaluation of Domestic Household Cooking Energy choices (DHCE) in sparsely populated areas

\begin{tabular}{llll}
\hline $\mathbf{S} / \mathbf{N}$ & L G & Energy consumption of DHCE in sparsely populated areas (MJ) & Cost(N) \\
\hline 1 & Irepodun/lfelodun & $126,815.60$ & $396,184.23$ \\
2 & Ise-orun & $93,093.25$ & $285,730.05$ \\
3 & Emure & $92,658, .90$ & $290,778.00$ \\
4 & Efon & $90,406.85$ & $301,724.27$ \\
5 & llejemeje & $83,293.00$ & $252,820.11$ \\
& Total & $486,267.60(37 \%)$ & $1,527,236.66$ \\
\hline
\end{tabular}


The values obtained show that, the low income earners had the higher energy consumption compared to high income earners at both level of significant. The test is further confirmed using paired T-test statistical tool as illustrated in Table 9 .

\subsection{Results Analysis between Low and High Income Earners Using Paired t- test}

Table 9 shows by analysis the results obtained from households' energy consumption in the ten selected locations.

From t-table,$\left(t_{9}, 0.025\right)$ and at $5 \%$ level of significant, the low income earners had 34,349.90 MJ while the high income earners consumed 19,202.06 MJ. Similarly, from t- table,$\left(t_{9}, 0.05\right)$ and at $10 \%$ level of significant, the low income earners had $32,908.84 \mathrm{MJ}$ while the high income earners consumed 20,643.98 MJ. It is evident from the evaluation above at both $5 \%$ and $10 \%$ level of significance when paired t-test was used that, there was a substantive significant difference between the energy consumption by the low and high income earners. At $5 \%$ level of significant, the energy consumed by low income earners $(34,349.90$ MJ) against 19,202.06 MJ in favour of high income earners. On further test at $90 \%$ confidence interval, the energy consumed by low income earners was $32,908.8 \mathrm{MJ}$ whereas 20,643.98 MJ was in favour of high income earners. It is an established fact at this juncture that, the energy consumed by low income earners was greater than that of the high income earners.

Table 6. Energy consumption of Domestic Household Cooking Energy (DHCE) by low and high income earners generated in visited areas

\begin{tabular}{lllllllc}
\hline S/N & LG & ECLIE (MJ) & ECHIE (MJ) & TEC by LHIE & PEC by LIE & PEC by HIE & $\begin{array}{l}\text { Total } \\
(\%)\end{array}$ \\
\hline 1 & Ado & $109,934.01$ & $91,611.68$ & $201,545.69$ & 54.6 & 5.4 & 100 \\
2 & ljero & $108,310.27$ & $66,652.48$ & $174,962.75$ & 61.9 & 38.1 & 100 \\
3 & EW & $90,318.75$ & $82,464.95$ & $172,783.70$ & 52.3 & 47.7 & 100 \\
4 & Ikole & $80,325.17$ & $65,025.13$ & $145,350.30$ & 55.3 & 44.7 & 100 \\
5 & ESW & $77,929.48$ & $54,839.27$ & $132,768.75$ & 58.7 & 41.3 & 100 \\
6 & Irepodun & $77,192.10$ & $49,623.50$ & $126,815.60$ & 60.9 & 39.1 & 100 \\
7 & Ise-orun & $65,588.43$ & $27,504.82$ & $93,093.25$ & 70.5 & 29.5 & 100 \\
8 & Emure & $62,544.76$ & $30,114.14$ & $92,658.90$ & 67.5 & 32.5 & 100 \\
9 & Efon & $60,271.23$ & $30,135.62$ & $90,406.85$ & 66.7 & 33.3 & 100 \\
10 & Ilejemeje & $58,305.10$ & $24,987.90$ & $83,293.00$ & 70.0 & 30.0 & 100 \\
& Total & $790,719.30$ & $522,959.49$ & $1,313,678.80$ & & & \\
\hline
\end{tabular}

ECLIE = Energy Consumption by Low Income Earners; ECHIE= Energy Consumption by High Income Earners; $T E C=$ Total Energy Consumption; $P E C=$ Percentage Energy Consumption; LIE = Low Income Earners; HIE = High Income Earners

Table 7. Energy consumption by low and high income earners generated in Ekiti State

\begin{tabular}{llllllll}
\hline S/N & $\begin{array}{l}\text { Local } \\
\text { government }\end{array}$ & $\begin{array}{l}\text { Energy } \\
\text { consumed } \\
\text { by LIE(MJ) }\end{array}$ & $\begin{array}{l}\text { Energy } \\
\text { consumed } \\
\text { by HIE (MJ) }\end{array}$ & $\begin{array}{l}\text { Total } \\
\text { energy } \\
\text { consumed } \\
\text { by LIE and } \\
\text { HIE (MJ) }\end{array}$ & $\begin{array}{l}\text { Percentage } \\
\text { of energy } \\
\text { consumed } \\
\text { by LIE (MJ) }\end{array}$ & $\begin{array}{l}\text { Percentage } \\
\text { of energy } \\
\text { consumed } \\
\text { by HIE (MJ) }\end{array}$ & $\begin{array}{l}\text { Total } \\
\text { (\%) }\end{array}$ \\
\hline 1 & Ado & $109,934.01$ & $91,611.68$ & $201,545.69$ & 54.6 & 5.4 & 100 \\
2 & ljero & $108,310.27$ & $66,652.48$ & $174,962.75$ & 61.9 & 38.1 & 100 \\
3 & EW & $90,318.75$ & $82,464.95$ & $172,783.70$ & 52.3 & 47.7 & 100 \\
4 & Ikole & $80,325.17$ & $65,025.13$ & $145,350.30$ & 55.3 & 44.7 & 100 \\
5 & ESW & $77,929.48$ & $54,839.27$ & $132,768.75$ & 58.7 & 41.3 & 100 \\
6 & Irepodun & $77,192.10$ & $49,623.50$ & $126,815.60$ & 60.9 & 39.1 & 100 \\
7 & Ise-orun & $65,588.43$ & $27,504.82$ & $93,093.25$ & 70.5 & 29.5 & 100 \\
8 & Emure & $62,544.76$ & $30,114.14$ & $92,658.90$ & 67.5 & 32.5 & 100 \\
9 & Efon & $60,271.23$ & $30,135.62$ & $90,406.85$ & 66.7 & 33.3 & 100 \\
10 & Ilejemeje & $58,305.10$ & $24,987.90$ & $83,293.00$ & 70.0 & 30.0 & 100 \\
& Total & $790,719.30$ & $522,959.49$ & $1,313,678.80$ & & & \\
\hline
\end{tabular}


Table 8. Comparison of energy consumption between the low and high income earners using independent test

\begin{tabular}{|c|c|c|c|c|c|c|c|}
\hline $\mathrm{S} / \mathrm{N}$ & Local Government & $\begin{array}{l}\text { Energy consumed by LIE } \\
(\mathrm{MJ}) \mathrm{X}_{\mathrm{A}}\end{array}$ & $\begin{array}{l}\text { Energy consumed by HIE } \\
(M J) X_{B}\end{array}$ & $\begin{array}{l}\left(\mathrm{X}_{\mathrm{A}}-\bar{X}_{A}\right) \\
(\mathrm{MJ})\end{array}$ & $\begin{array}{l}\left(\mathrm{X}_{\mathrm{A}}-\bar{X}_{A}\right)^{2} \\
(\mathrm{MJ})\end{array}$ & $\begin{array}{l}\left(\mathbf{X}_{\mathrm{B}}-\bar{X}_{B}\right) \\
(\mathbf{M J})\end{array}$ & $\begin{array}{l}\left(\mathrm{X}_{\mathrm{B}}-\bar{X}_{B}\right)^{2} \\
(\mathrm{MJ})\end{array}$ \\
\hline 1 & Ado & $109,934.01$ & $91,611.68$ & $30,862.08$ & $952,467,981.90$ & $39,315.73$ & $1,545,726,625.00$ \\
\hline 2 & liero & 108.310 .27 & 66.652 .48 & $29,238.34$ & 854.880 .526 .00 & $14,356.53$ & $206.109,953.60$ \\
\hline 3 & EW & $90,318.75$ & $82,464.95$ & $11,246.82$ & $126,490,960.10$ & $30,169.00$ & $910,168,561.00$ \\
\hline 4 & Ikole & $80,325.17$ & $65,025.13$ & $1,253.24$ & $1,570,610.50$ & $12,729.18$ & $162,032,023.50$ \\
\hline 5 & ESW & $77,929.48$ & $54,839.27$ & $-1,142.45$ & $1,305,192.00$ & $2,543.32$ & $6,468,476.62$ \\
\hline 6 & Irepodun & $77,192.10$ & $49,623.50$ & $-1,879.83$ & $3,533,760.83$ & $-2,672.45$ & $7,141,989.00$ \\
\hline 7 & Ise-orun & $65,588.43$ & $27,504.82$ & $-13,483.50$ & $181,80,772.30$ & $-24,791.13$ & $614,600,126.70$ \\
\hline 8 & Emure & $62,544.76$ & $30,114.14$ & $-16,527.17$ & $273,147,348.20$ & $-22,181.81$ & $492,032,694.90$ \\
\hline 9 & Efon & $60,271.23$ & $30,135.62$ & $-18,800.70$ & $353,466,320.50$ & $-22,160.33$ & $491,080,225.70$ \\
\hline \multirow[t]{2}{*}{10} & Ilejemeje & $58,305.10$ & $24,987.90$ & $-20,766.83$ & $431,261,228.20$ & $-27,308.05$ & $745,729,594.80$ \\
\hline & Total & $790,719.30$ & $522,959.49$ & & $3,179,928,701.0$ & & $5,181,090,271.0$ \\
\hline
\end{tabular}

Table 9. Comparison of energy consumption between the low and high income earners in Ekiti State using paired t-test

\begin{tabular}{|c|c|c|c|c|c|}
\hline $\mathbf{S} / \mathbf{N}$ & Local Government & $\begin{array}{l}\text { Energy consumed by low income } \\
\text { earners }(\mathrm{MJ}) \\
\mathrm{X}_{\mathrm{A}}\end{array}$ & $\begin{array}{l}\text { Energy consumed by high income } \\
\text { earners (MJ) } \\
X_{B}\end{array}$ & $\begin{array}{l}\mathrm{d}=\left(X_{A}-X_{B}\right) \\
(\mathrm{MJ})\end{array}$ & $\begin{array}{l}\left(d_{i}-\bar{d}\right)^{2} \\
(M J)\end{array}$ \\
\hline 1 & Ado & $109,934.01$ & $91,611.68$ & $18,322.33$ & $71,464,198.32$ \\
\hline 2 & ljero & $108,310.27$ & $66,652.48$ & $41,657.79$ & $221,468,268.90$ \\
\hline 3 & EkitiWest & $90,318.75$ & $82,464.95$ & $7,853.80$ & $358,048,896.00$ \\
\hline 4 & Ikole & $80,325.17$ & $65,025.13$ & $15,300.04$ & $131,697,198.90$ \\
\hline 5 & ESW & $77,929.48$ & $54,839.27$ & $23,090.21$ & $13,584,900.49$ \\
\hline 6 & Irepodun & $77,192.10$ & $49,623.50$ & $27,568.60$ & $628,246.46$ \\
\hline 7 & Ise-orun & $65,588.43$ & $27,504.82$ & $38,083.61$ & $127,862,496.20$ \\
\hline 8 & Emure & $62,544.76$ & $30,114.14$ & $32,430.62$ & $31,974,953.53$ \\
\hline 9 & Efon & $60,271.23$ & $30,135.62$ & $30,135.61$ & $11,287,113.74$ \\
\hline \multirow[t]{2}{*}{10} & Ilejemeje & $58,305.10$ & $24,987.90$ & $33,317.20$ & $42,787,559.09$ \\
\hline & Total & $790,719.30$ & $522,959.49$ & $267,759.81$ & $1,010,803,832.00$ \\
\hline
\end{tabular}




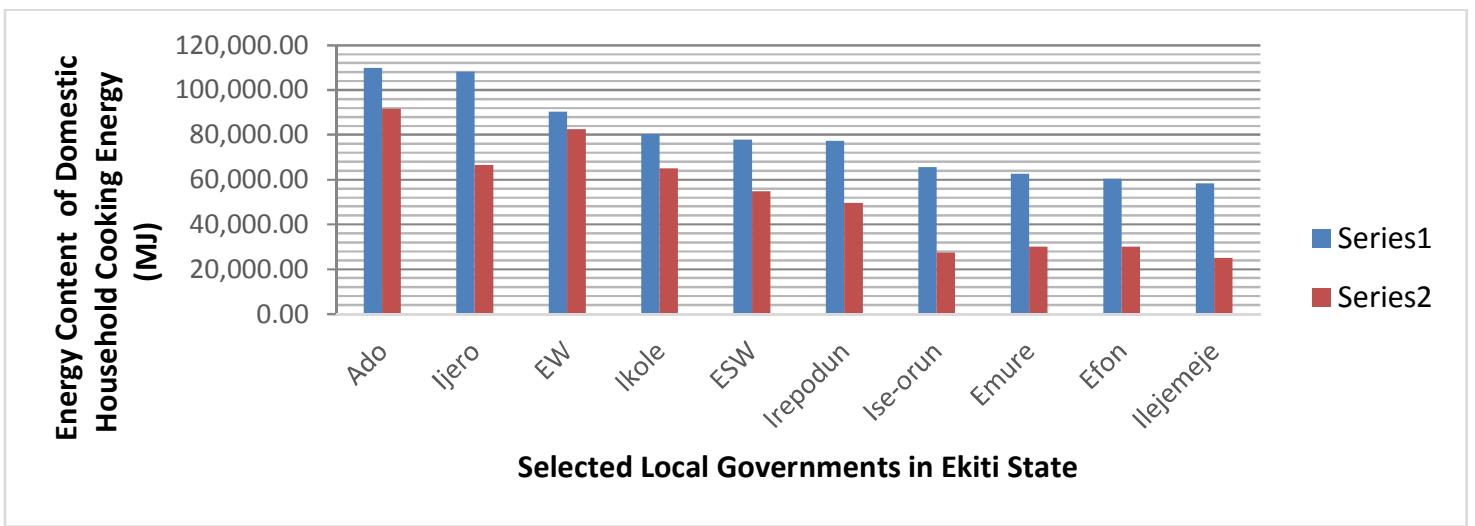

Fig. 1. Multiple bar charts of energy content of Domestic Household Cooking Energy (DHCE) consumption by the low and high income earners

Series 1: LIE: Low Income Earners; Series 2: HIE: High Income Earners

The multiple bar charts showed in above Fig. 1 revealed the differences between energy consumption by low and high income earners in Ekiti State. It was obvious that, the low income earners have more respondents than high income earners. Hence, the low income earners consumed more energy than the high income earners as illustrated with values and the height of the bars.

\section{CONCLUSIONS}

The type of energy used by the majority of households reflects the extent of economic development and civilization attained. The major reason why households have shifted from the use of convectional fuel to alternative domestic energy source was as a result of the relative cheap prices of these energy and sources. Biomass is the most preferred fuel in sparsely populated areas due to the epileptic nature of electricity in the State and, scarcity and hike in price of kerosene and LPG. Thus, fuel wood was the alternative energy used by the various households to mitigate the impact of the high cost of other domestic fuels. Generally, the energy consumed by the densely populated group (827,411.20 MJ) was extremely higher than sparsely dwellers $(486,267.60 \mathrm{MJ})$ but, in terms of income level; the low income earners consumed more energy $(790,719.30 \mathrm{MJ})$ than high income earners with 522,959.49 MJ. Among the domestic energy choices consumption via kerosene $(388,557.10 \mathrm{MJ})$, LPG $(590,055.35$ MJ), charcoal $(147,846.90 \mathrm{MJ})$, fuel wood $(84,789.50 \mathrm{MJ})$ and electricity $(102,429.95 \mathrm{MJ})$, the result showed that, biomass remains the most fuel used for cooking in the sparsely populated areas with fuel wood being the preferable energy source while gas and electricity were predominately used in the densely populated areas. The study established that, fuel wood was the poor man's energy source $(6.5 \%)$ as well as charcoal (11.2\%) majorly used in sparsely populated areas with high demand. Kerosene consumption (29.6\%) was positively and significantly influenced by income, population and common in both locations while, LPG $(44.9 \%)$ and electricity $(7.8 \%)$ were used mainly in the densely populated areas. The result therefore showed that, the low income earners consumed more energy than the high income earners as a result of frequency of cooking and smaller unit purchase of their choices of energy. The paper provided a valid and reliable qualitative and quantitative database on the most economically viable domestic fuel of choice, effective energy cost management (for the low income earners to spend less on energy by reducing cooking frequency and to buy in bulk) coupled with poverty reduction in relation to household's income.

\section{COMPETING INTERESTS}

Authors have declared that no competing interests exist.

\section{REFERENCES}

1. IEA. World energy outlook: Energy and sustainable development in Nigeria: The way forward; 2003.

2. ECN. Energy and sustainable development in Nigeria: The way forward; 2015.

Available:www.energysustainsoc.com 
3. ECN. Energy and sustainable development in Nigeria: The way forward; national energy policy; Federal Republic of Nigeria, Abuja; 2003.

4. Elhadify MA, Manzoorul AA. Electricity energy consumption in selected residential buildings at king felid university of petroleum and minerals, Dhahran, Saudi Arabia; 2011.

5. IEA. Buildings and climate change: Status, challenges and opportunities. Energy Economics. 2005;6:31.

6. Ouedraogo NS. Energy consumption and human development: Evidence from a panel co integration and error connection model. Journal of Energy Development. 2013;21(2):28-41.

7. Yaqub JO, Olateju OA, Aina B. Comparative analysis of household energy used in Nigeria: A case study of Ikeja and Oke-oko area in Ikorodu area of Lagos. Renewable Energy. 2008;2(1):4-9.

8. Federal Office of Statistics (FOS). National integrated survey of households: Report of general household survey; Lagos, Nigeria; 1992.

9. Amous, Samir. FAO: The role of wood energy in Africa, west regional studies, Nigeria. Journal of Engineering and Applied Sciences. 1997;5(3):23-33.

10. Adeyemo SB, Odukwe AO. Energy conservation as a viable pathway towards energy stability. Journal of Engineering and Applied Sciences. 2008;3(3):233-238.
11. Osueke CO, Ezugwu CA. Study of Nigerian energy resources and its composition. International Journal of Scientific and Engineering Research. 2011;2(12):2229-5518.

12. Akinbami JF, llori MO, Oyebisi TO, Akinwumi IO, Adeoti O. Biogas energy used in Nigeria: Current status, future prospect and policies implication. Renewable and Sustainable Energy Review. 2001;5:97-112.

13. Hui SC. From renewable energy to sustainability: The challenge for Hong Kong; Hong Kong institution of engineers. 1997;3:351-358.

14. Chineke TC, Igwiro EC. Urban and rural electrification: Enhancing the energy sector in Nigeria using photovoltaic technology. African Journal Science and Tech. 2008;9 (1):102-108.

15. Mobolaji E, Aluko k. The economic development of Ekiti state: Prospects and challenges. A paper presented at Ekiti day Ado Ekiti, Nigeria; 2003.

16. Ekiti State Bureau of Statistics. Ministry of budget and economic planning, Ado Ekiti; Ekiti State; 2015.

17. Available:http://www.partstap.com 2014.

18. Eastop TD, McConkey A. Use and energy management: Energy consumption and cost. Applied thermodynamics for engineering technologist by Darling Kindersley (India) Pvt. Ltd; licenses of Pearson Education in South Asia. 2006;5: 700-704.

(c) 2017 Oginni et al.; This is an Open Access article distributed under the terms of the Creative Commons Attribution License (http://creativecommons.org/licenses/by/4.0), which permits unrestricted use, distribution, and reproduction in any medium, provided the original work is properly cited.

Peer-review history:

The peer review history for this paper can be accessed here: http://sciencedomain.org/review-history/19329 